TAPROBANICA, ISSN 1800-427X. October, 2012. Vol. 04, No. 02: pp. 117.

(C) Taprobanica Private Limited, 146, Kendalanda, Homagama, Sri Lanka.

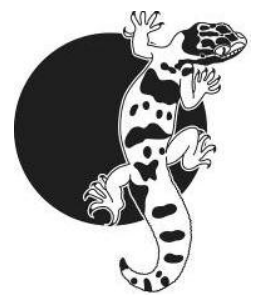

\section{Cannibalism of Indian Palm Squirrel (Funambulus palmarum)}

The palm squirrel is one of the common small mammals in Sri Lanka and the Indian Palm Squirrel (Funambulus palmarum) is the commonest of all being distributed throughout the island. All palm squirrels are essentially herbivores, however diet varies depending on the species. $F$. palmarum has a broad, opportunistic diet, consuming a range of foods that vary depending on season (Phillip, 1980). Its diet includes nuts, a range of seeds, fruits, flowers, young shoots, barks, lichens and it occasionally eats insects such as termites and beetles (Philiip, 1980). Some semi-tame individuals in the urban areas are fond of bread and rice (Phillip, 1980). We were able to observe cannibalistic behavior of this species from an anthropogenic habitat and this is the first record on cannibalism of Indian Palm Squirrel reported from Sri Lanka. The observation was made on 25 August 2010 at 15:55 $\mathrm{hr}$ at an anthropogenic habitat at Kesbawa of Colombo District of Sri Lanka. A palm squirrel nest had been built $2.3 \mathrm{~m}$ above ground on a lamp on the wall of a verandah. Two litters inhabited the nest and were 5 days old on the day of observation. At 15:59 hr an adult male Indian palm squirrel arrived and entered into one chamber of the nest. The adult male was holding the neck of one of the litter in its mouth. The pup started to give out a repeated alarm call. Responding to the alarm call, the mother, who was approximately $10 \mathrm{~m}$ from the nest, came towards the male and bit the tail of the adult male. However the male dragged the pup out from the nest. The female chased the male for a while and started to give alarm calls. The male after moving out walked along the wall and jumped onto the gate post about $3 \mathrm{~m}$ from the nest. The pup started to give out an alarm call but this time there was no response from the female. The male walked along the gate post to the opposite side and then jumped onto a creeper on a Cassia fistula
(Family: Fabaceae) tree and rested on it. At around 16:03 hr the male started to feed on the pup. Feeding was initiated from the the head. During the feeding process the male changed its sitting position several times and moved its tail horizontally. It rested for around 2 minutes, curled its tail, looked around and continued devouring the head of the pup. After continuing feeding on the head, the male tried to jump onto another creeper while holding the pup by the fore arms. When trying to move to the other creeper, the pup fell onto the ground approx. $1.8 \mathrm{~m}$. The male climbed down and searched the ground for around 30 minutes but could not find the dead pup. It then left the ground and climbed back onto the same tree. After that dead pup was photographed (Fig. 1).

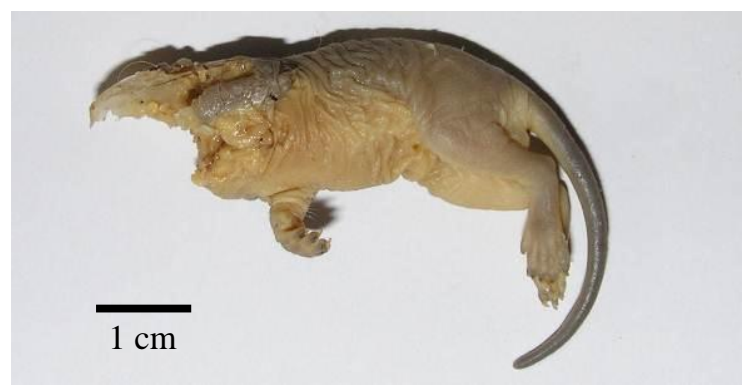

Figure 1: The fallen dead Funambulus palmarum pup, with its head consumed.

\section{Literature cited}

Phillips, W. W. A., 1980. Manual of the Mammals of Sri Lanka - part II $\left(2^{\text {nd }}\right.$ revised edition). Wildlife and Nature Protection Society of Sri Lanka: 267.

Submitted: 16 June 2012, Accepted: 03 July 2012 Sectional Editor: Colin A. Chapman

G. M. Edirisinghe ${ }^{1}$ and B. S. A. T. H. Sudasinghe $e^{1,2}$

${ }^{1}$ Young Zoologists' Association of Sri Lanka, National Zoological Gardens, Sri Lanka. 2 hsudasinghe@gmail.com 